\title{
RELATIONSHIP OF LECTIN PROTEINS AND HEALTH: STUDIES ON PRODUCT DEVELOPMENT WITHOUT LECTIN
}

\author{
H. Uğur Öncel ${ }^{1}$, Duygu Toker ${ }^{\circledR}$, Hayrettin Mutlu ${ }^{3}$, Fatih Tarlak ${ }^{1}$ \\ ${ }^{1} \dot{I}_{s t a n b u l ~ G e d i k}$ University, Nutrition and Dietetics Department \\ ${ }^{2} \dot{I}_{\text {stinye University, Gastronomy and Culinary Arts Department }}$ \\ ${ }^{3} \dot{I}_{\text {stanbul Health and Technology University, Nutrition and Dietetics Department }}$ \\ 凶toker.duygu80@gmail.com \\ https://doi.org/10.34302/crpjfst/2021.13.1.5

\begin{tabular}{ll}
\hline Article history: & ABSTRACT \\
Received: & Foods that contain lectin protein prevent the body from reaching the required \\
18 June 2020 & nutritional content, thus not completely benefit, when consumed. In the \\
Accepted: & literature, it is reported that people with lectin sensitivity could have health \\
3 January 2021 & problems. Among those are insulin resistance, obesity, leptin sensitivity, \\
Keywords: & gastrointestinal system disorders due to various toxic effects. Germination, \\
Lectin Proteins, Anti-Nutrient, & soaking, fermentation and cooking processes are important processes in \\
Fast-Food & reducing the amount of lectin in foods. In some studies, it has been reported \\
& that lectin-free diet shows improvement in autoimmune diseases. While \\
& there are many studies in the literature aimed at decreasing the lectin level, \\
& research on developing the lectin-free product is ongoing. The aim of our \\
& study was to develop alternative food and snack formulas free of lectin \\
& protein. Therefore, traditional cookies, pretzels and cakes were used as the \\
& basis as the commonly consumed snacks. In the formulas, instead of white \\
& flour, Almond and Coconut flour without lectin protein was used. The \\
& differences in perceptions between consuming lectin and non-lectin products \\
& were evaluated according to descriptive statistics methods. In conclusion, a \\
& significant difference was found between perception of the lectin-free snacks \\
and the lectin-containing snacks. When examined according to gender with \\
regards to the taste and interest; while women were more interested in \\
gluten-free and lectin-free products than men, p <0.05), there was no \\
difference in flavor scores (p>0.05).
\end{tabular}

\section{Introduction}

Apart from pathological factors such as, bacteria, viruses, fungi and parasites; food poisoning is a metabolic reaction that can also be caused by different structures contained in food products (Peumans and Van Damme, 1995). These different active structures in the natural structure of plants, while providing the necessary opportunities for their survival, sometimes can cause serious toxic effects when consumed (Tamimi et al., 2008). The main function of lectins in plants is to protect the seeds of the plant from harmful effects and ensure the survival of its species. They function as powerful insecticides and microorganism killers. (Barooah, et al., 2017) One of the most important factors that contributes to health hazard is considered anti-nutrients when a food products is not properly prepared. Anti-nutrients are structures that prevent the absorption of consumed food by the body. Due to the nature of these substances, the digestive system is unable to absorb the food received and thus cannot benefit from the food as intended. The most common known anti-nutrients are; phytate, saponin, tanin and lectin (Adebanke et al.,2015; Petroski and Minich, 2020; Popova and Mihaylova, 2019; Oke et al., 2020; Vasconcelos 
and Oliveira, 2004). Lectins are substances in protein or glycoprotein structure that can bind specifically to glycosides in the cell membrane and organelles (Akande et al., 2010; Hamid et al., 2013). The reactions of these proteins when bound to carbohydrates in the cell membranes are thought to play a role in gaining excessive weight and developing certain diseases (Day et al., 2002; Freed, 1999; Sharon and Lis, 1997; Werz and Seeberger, 2005;). Many lectin proteins exhibit inflammation-inducing immunotoxic, neurotoxic and cytotoxic effects. Some lectin proteins hemagglutinate, hence increase blood viscosity, affect gene expression, and disrupt endocrine function (Zwolak, 2014). Because these effects of lectins cannot be felt during nutrition, they can remain hidden, but later revealed during absorption in intestinal cells when reaction occurs with antibodies. It is reported that health-related threats to lectins could arise unless most of the plant-based food is carefully consumed (Mishra, et al., 2019). Reducing the amount of lectin in food products should minimize the damages of lectin to the body. Methods used to reduce the amount of lectin are; germination, soaking, fermentation and cooking thoroughly (Ibrahim et al., 2002). High-pressure cooking of the food provides the decomposition of lectins. Food cooking or applications as such before cooking are proved effective in their digestibility. The volume of water used in the cooking process, the properties of the food to be cooked, the temperature used in cooking and the cooking methods are the factors contribute to the nutritional content (Larrosa et al., 2015; Yu-Wei and Wei-Hua, 2013;). According to Van der Poel, (1990), the starch digestibility is attributed to the swelling and tearing of starch granules, the separation of various bean components during cooking and the inactivation of $\alpha$-amylase inhibitors. The inhibitors in the structure of heat sensitive proteins can inactivate anti nutritional agents such as lectins and various volatile compounds during the process of cooking. It is known that trypsin inhibitors contained in pods, chickpeas and lentils, which are kept in $121^{\circ} \mathrm{C}$ degree hot water for 30 minutes, are completely suppressed. A significant decrease was observed in proteolytic enzyme inhibitory activities of beans prepared by the fast cooking method. In this context, the aim of our study is to develop non-lectin food products and compare them with similar food products consumed in daily life.

\section{Materials and methods}

The ingredients used in this study are; almond flour which was milled in Datça region Village Products Company and Coconut Flour, which was obtained from a chain grocery. End products are classified as follows:

- Product A, cookies produced with lectin-free and gluten-free almond flour with tahini and walnut,

- Product B, cookies produced with lectincontaining white flour with tahini and walnut,

- Product C, cheese-herbal sesame bagels produced with lectin-free and gluten-free almond flour,

- Product D, cheese herbal sesame bagels produced with lectin-containing white flour,

- Product E, cake produced with lectin-free and gluten-free almond and coconut flour,

- Product F, cake produced with lectin-containing white flour.

The study was conducted with a total of 30 healthy volunteers (15 females and 15 males) aged between 35-45 years old and selected randomly using the free panellist method (Kilcast, 2010). In the experiment, 30 panellists were informed about panel questions first. In this study, the volunteers have been served with both packaged, lectin-rich products and similar lectin-free products obtained from the market. Experiments were performed using a completely randomized design. Data were subjected to oneway analysis of variance (ANOVA). Mean separations were performed using Tukey's least significant difference (LSD) procedure in Matlab 7.12.0 (R2011a) software (MathWorks Inc., 130 Natick, MA, USA). Differences at $p<$ 0.05 were considered significant (Tarlak et al., 2020).

Humidity content, dry matter percentage, carbohydrate percentage, protein percentage, ash percentage, dietary fibre percentage, energy value, fat percentage, and gluten content were 
also analysed using proper standard methods and products were compared.

\section{Results and discussions}

Table 1 and Table 2 show the participants' evaluation of the products $\mathrm{A}$ and $\mathrm{B}, \mathrm{C}$ and $\mathrm{D}, \mathrm{E}$ and $\mathrm{F}$ in terms of differences, and the results they found to be different in terms of flavour. While $50 \%$ (15 people) stated that there was a taste difference between $\mathrm{A}$ and $\mathrm{B}$ cookie products, the remaining 50\% (15 people) stated that there was no difference. In addition, $80 \%$ of 15 people (12 people) stated that the A product was richer in flavour. 20\% (3 people) think that $\mathrm{B}$ is more delicious in terms of flavour.

While $63.3 \%$ (19 people) stated that there was a taste difference between $\mathrm{C}$ and $\mathrm{D}$ products, $36.7 \%$ (11 people) stated that there was no difference between the two products. In addition, while $63.2 \%$ (12 people) stated that $\mathrm{C}$ product was more delicious than $\mathrm{D}$ product, $36.8 \%$ (7 people) stated that they had the opposite opinion and said that the white flour cheese-herb sesame product was more delicious.

90\% (27 people) stated that there was a difference in flavour between $\mathrm{E}$ product and $\mathrm{F}$ products, while $10 \%$ ( 3 people) stated that there was no difference between the two products. $74.1 \%$ (20 people) of the 27 people who stated that there was a difference between the two products stated that the E product was richer in flavour. $25.9 \%$ ( 7 people) think that $\mathrm{F}$ is more delicious in terms of flavour.

People seem to think that lectin-free and gluten-free products are more delicious in flavour. Individuals participating in the study think that the shape of the products produced with lectin-free and gluten-free ingredients is smooth and round, the shell is smooth and crisp, the volume is light and proportionate, the texture is elastic and light, the pores are smooth and thin-walled and the product colour is in accordance with the ingredient material used. Mert et al. (2015) has investigated the attributes of different flour varieties on gluten-free wafer leaf quality. In his study where wafer layers' texture profiles were assessed with regard to rigidness, only rice corn-based samples and corn wheat products have more rigidity compared to others. Romero, 2017, in their research on the viscoelastic properties of the gluten-free pasta, it was concluded that dough mixture with the addition of casein has been lighter than the egg white color and the redness-yellowness values have decreased. Furthermore, when XG (Xanthan Gum) and KMS (carboxymethyl cellulose) were used as gum, they reached a structure closer to the desired level when making pasta. Turkut et al. (2015), in his research on dough structure and product properties in sour yeast and gluten-free bread production, concluded that added quinoa flour increased viscosity, elastic modulus $\left(G^{\prime}\right)$ and viscous modulus values. The addition of kinoa and buckwheat increased the protein value of the breads, decreased the brightness value of the bread and crust, and increased the redness value ( $p<0.05$ ). Yildiz and Dogan (2014), in their study of the effects of different formulation, baking and storage times on gluten-free cake quality, found out that cakes produced by partial baking method had higher inner property scores, whereas outer property scores, specific volumes, hardness and chewability values were lower. It was concluded that there was no statistical difference between fresh cakes prepared for each cake and full or partially cooked cakes, considering all of the cake characteristics. Martinescu et al. (2020) have concluded that gluten-free flour and almond flour cookies are more favourable than other cookies with respect to their appearance, flavour, texture and smell, in their study based on the averages. The purchase intention also confirms this appreciation. As a result of cookies made with gluten-free flour and almond flour $(n=47)$, it is observed that cookies made with gluten-free flour and almond flour are more preferred in terms of purchase intention.

Tests were carried out in the accredited food analysis laboratory to evaluate the products' nutritional properties with different contents that we designed and produced. The product results in terms of humidity, dry matter percentage, carbohydrate percentage, protein percentage, ash percentage, dietary fibre percentage, energy value, fat percentage, and gluten content are shown in Table 3. 
There was significant difference $(\mathrm{p}<0.05)$ between $\mathrm{A}, \mathrm{C}$ and $\mathrm{E}$ products which are lectin and gluten free and $\mathrm{B}, \mathrm{D}$ and $\mathrm{F}$ commercial products which are including lectin and gluten in terms of carbohydrate percentage, protein percentage and dietary fibre percentage. A, C and $\mathrm{E}$ products have higher protein percentage and dietary fibre percentage and lower carbohydrate percentage than $\mathrm{B}, \mathrm{D}$ and $\mathrm{F}$. Especially dramatic increasing in dietary fibre percentage is led to considered healthy food. Additionally, lower carbohydrate percentage and higher protein contents obtained for A, C and $\mathrm{E}$ products increase nutrient property.

Table 1. Participants' perceptions when compared; A and B, C and D, E and F products in terms of differences and taste evaluation.

\begin{tabular}{|c|c|c|c|c|c|c|c|c|c|c|c|}
\hline & \multirow{2}{*}{$\begin{array}{l}\text { YES } \\
\frac{0}{e} \\
\frac{\mathscr{E}}{0} \\
\overline{0} \\
\frac{0}{0} \\
\#\end{array}$} & \multirow{2}{*}{ 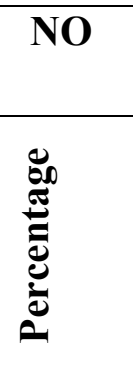 } & \multicolumn{8}{|c|}{ Which is more delicious? } \\
\hline & & & & $\begin{array}{l}\frac{n}{e} \\
\frac{0}{0} \\
\overline{0} \\
0 \\
0 \\
0 \\
\#\end{array}$ & êd & 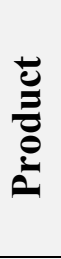 & 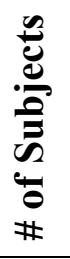 & م્0 & 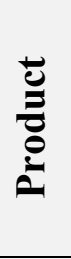 & 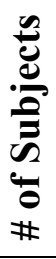 & : \\
\hline 1 & $\begin{array}{l}\text { Is there a } \\
\text { difference } \\
\text { between A } \\
\text { and B? }\end{array}$ & 15 & $50 \%$ & 15 & $50 \%$ & A & 12 & $80 \%$ & $\mathrm{~B}$ & 3 & $20 \%$ \\
\hline 2 & $\begin{array}{l}\text { Is there a } \\
\text { difference } \\
\text { between C } \\
\text { and D? }\end{array}$ & 19 & $63,3 \%$ & 11 & $36,7 \%$ & $\mathrm{C}$ & 12 & $63,2 \%$ & $\mathrm{D}$ & 7 & $36,8 \%$ \\
\hline 3 & $\begin{array}{l}\text { Is there a } \\
\text { difference } \\
\text { between } E \\
\text { and } F \text { ? }\end{array}$ & 27 & $90 \%$ & 3 & $10 \%$ & $E$ & 20 & $74,1 \%$ & $\mathrm{~F}$ & 7 & $25,9 \%$ \\
\hline
\end{tabular}

Table 2. Total Quality and Sub-parameter Score Averages of Participants who have tried A, C and E Products.

\begin{tabular}{|l|c|c|c|c|c|c|c|c|}
\hline & Shape & Shell & $\begin{array}{c}\text { Volum } \\
\mathbf{e}\end{array}$ & $\begin{array}{c}\text { Textur } \\
\mathbf{e}\end{array}$ & Pores & Color & Taste & $\begin{array}{c}\text { Total } \\
\text { Average }\end{array}$ \\
\hline $\begin{array}{l}\text { A } \\
\text { Product }\end{array}$ & 8.67 & 8.70 & 8.73 & 8.13 & 8.43 & 8.37 & 36.77 & 87.80 \\
\hline $\begin{array}{l}\text { C } \\
\text { Product }\end{array}$ & 8.10 & 8.00 & 8.27 & 8.20 & 8.30 & 8.77 & 35.63 & 85.27 \\
\hline $\begin{array}{l}\text { E } \\
\text { Product }\end{array}$ & 8.83 & 8.77 & 8.83 & 8.90 & 9.07 & 8.87 & 36.97 & 90.23 \\
\hline
\end{tabular}


Table 3. Nutritional content analysis result of the product.

\begin{tabular}{|c|c|c|c|c|c|c|c|}
\hline \multirow{2}{*}{ Analyses } & \multicolumn{6}{|c|}{ Products } & \multirow{2}{*}{ Method } \\
\hline & A product & $\begin{array}{c}\text { B } \\
\text { product }\end{array}$ & $\begin{array}{c}\mathrm{C} \\
\text { product }\end{array}$ & $\begin{array}{c}\text { D } \\
\text { product }\end{array}$ & $\begin{array}{c}\mathbf{E} \\
\text { product }\end{array}$ & $\begin{array}{c}\text { F } \\
\text { product }\end{array}$ & \\
\hline $\begin{array}{c}\text { Moisture } \\
\text { (\%) }\end{array}$ & 35.6 & 47 & 17.65 & 49.1 & 9.89 & 44.5 & $\begin{array}{l}\text { AOAC } \\
925.10 \\
(2005)\end{array}$ \\
\hline $\begin{array}{c}\text { Dry Matter } \\
(\%)\end{array}$ & 64.4 & 53 & 82.32 & 50.9 & 90.11 & 61.5 & $\begin{array}{l}\text { AOAC } \\
925.10 \\
(2005)\end{array}$ \\
\hline $\begin{array}{c}\text { Carbohydr } \\
\text { ate }(\%)\end{array}$ & 8.78 & 28.24 & 0.58 & 29.10 & 31.28 & 60.9 & $\begin{array}{l}\text { FAO } \\
(2003)\end{array}$ \\
\hline $\begin{array}{c}\text { Protein } \\
(\%)\end{array}$ & 10.35 & 5.15 & 24,14 & 4.54 & 18.56 & 7.9 & $\begin{array}{l}\text { NMKL } 6 \\
(2003)\end{array}$ \\
\hline $\begin{array}{l}\text { Ash } \\
(\%)\end{array}$ & 4.09 & 0.96 & 24.14 & 0.85 & 2.38 & 5.4 & $\begin{array}{c}\text { NMKL } \\
173(2005)\end{array}$ \\
\hline $\begin{array}{c}\text { Dietary } \\
\text { Fibre } \\
(\%)\end{array}$ & 11.55 & 1.35 & 6.69 & 0.84 & 11.10 & 5.2 & $\begin{array}{c}\text { NMKL } \\
129(2003)\end{array}$ \\
\hline $\begin{array}{c}\text { Energy } \\
(\mathbf{k c a l} / \mathbf{1 0 0 g}) \\
-(\mathbf{k j} / \mathbf{1 0 0 g})\end{array}$ & $\begin{array}{c}366 \\
- \\
1530 \\
\end{array}$ & $\begin{array}{c}292 \\
- \\
1220 \\
\end{array}$ & $\begin{array}{c}404 \\
- \\
1692 \\
\end{array}$ & $\begin{array}{c}276 \\
- \\
1155\end{array}$ & $\begin{array}{c}462 \\
- \\
1913\end{array}$ & $\begin{array}{c}323 \\
- \\
1352\end{array}$ & $\begin{array}{l}\text { FAO } \\
(2003)\end{array}$ \\
\hline $\begin{array}{c}\text { Fat } \\
\text { Content } \\
(\%) \\
\end{array}$ & 29.63 & 17.3 & 30.02 & 15.57 & 26.79 & 32.4 & $\begin{array}{c}\text { NMKL } \\
160(1998)\end{array}$ \\
\hline $\begin{array}{l}\text { Gluten } \\
\text { Control }\end{array}$ & $\begin{array}{c}\text { Not } \\
\text { detected }\end{array}$ & detected & $\begin{array}{c}\text { Not } \\
\text { detected }\end{array}$ & detected & $\begin{array}{c}\text { Not } \\
\text { detected }\end{array}$ & detected & $\begin{array}{c}\text { ISO } \\
21415-1 \\
(2006)\end{array}$ \\
\hline
\end{tabular}

\section{Conclusions}

In our study; it was concluded that women had more interest in gluten-free and lectin-free products than men. When evaluated according to the gender as perception of taste and interest; while women were more interested in gluten-free and lectin-free products than men $(p<0.05)$, there was no difference in flavour scores $(\mathrm{p}>$ 0.05). There was no gender-related differentiation between almond and coconut flour lectin-free and gluten-free cake and white flour cake. It was concluded that the changes in taste and nutritional quality of the products have a significant effect $(\mathrm{p}<0.05)$ on panellists choosing. Our intention is to contribute to the literature with our study, due to the limited number of studies in this specific area. It is highly recommended to conduct more scientific studies within this context and to increase the efforts to develop alternative products. 


\section{References}

Adebanke, B. M., Pacy, O.G., Folakemi, O.P., Lola, K.F., Adeoye, O.S., Onozare, A. K., \& Abdulhakeem, S. (2015). Effect of softening agents on the chemical and anti-nutrient compositions of fermented prosopis Africana seeds. Carpathian Journal of Food Science and Technology, 7, 115-123.

Akande, K.E., Doma, U.D., Agu, H.O., Adamu, H.M. (2010). Major Antinutrients Found in Plant Protein Sources: Their Effect on Nutrition. Pakistan Journal of Nutrition, 9, 827832.

AL-Tamimi, F.A., Hegazi, A.E.M. (2008). A Case of Castor Bean Poisoning. Sultan Qaboos University Medical Journal, 8, 83-87.

American Association of Cereal Chemists (2005) Solids (Total) and Moisture in Flour, Method 925.10. In: Official Methods of Analysis, $18^{\text {th }}$ Edition, AOAC International, Gaithersburg.

Barooah, N., Kunwar, A., Khurana, R., Bhasikuttan, A.C., Mohanty, J. (2017). Stimuli-Responsive Cucurbit [7] urilMediated BSA Nanoassembly for Uptake and Release of Doxorubicin. ChemistryAn Asian Journal, 12, 122-129.

D. Kilcast, (2010). Sensory analysis for food and beverage quality control: A practical guide CRC Press, Boca Raton.

Day, P.J., Pinheiro, T.J., Roberts, L. M., Lord, J. M. (2002). Binding of ricin Achain to negatively charged phospholipid vesicles leads to protein structural changes and destabilizes the lipid bilayer. Biochemistry, 41, 2836-2843.

Embaby, H.ES. (2010). Effect of soaking, dehulling, and cooking methods on certain antinutrients and in vitro protein digestibility of bitter and sweet lupin seeds. Food Science Biotechnology, 19, 1055-1062.
FAO, (2003) FAO Food and Nutrition, Paper 77 Food energy - Methods of analysis and conversion factors Food and Agriculture Organization of the United Nation, FAO, Rome, Italy/Washington, DC, USA.

Freed, DLJ. (1999). Do dietary lectins cause disease? The evidence is suggestiveand raises interesting possibilities for treatment. British Medical Journal, 318, 1023-1024.

Hamid, R., Masood, A., Wani, I.H., Rafiq, S. (2013). Lectins: proteins with diverse applications. Journal of Applied Pharmaceutical Science, 3, S93-S103.

Ibrahim, S.S., Habiba, R.A., Shatta, A.A., Embaby, H.E. (2002). Effect of soaking, germination, cooking and fermentation on antinutritional factors in cowpeas. Food/Nahrung, 46, 92-95.

ISO 21415-1, (2006) Wheat and wheat flour. Gluten content. Part 1: Determination of wet gluten by a manual method.

Larrosa, V., Lorenzo, G., Zaritzky, N., Califano, A. (2015). Dynamic rheological analysis of gluten-free pasta as affected by composition and cooking time. Journal of Food Engineering, 160, 11-18.

Martinescu, C. D., Sârbu, N. R., Velciov, A. B., Stoin, D. (2020). Nutritional and sensory evaluation of gluten-free cake obtained from mixtures of rice flour, almond flour and arrowroot flour. Journal of Agroalimentary Processes and Technologies, 26, 368374.

Mert, S., Sahin, S., Sumnu, G. (2015). Development of gluten-free wafer sheet formulations. LWT-Food Science and Technology, 63, 1121-1127.

Mishra, A., Behura, A., Mawatwal, S., Kumar, A., Naik, L., Mohanty, S. S., Dhiman, R. (2019). Structure-function and application of plant lectins in disease 
biology and immunity. Food and Chemical Toxicology, 134, 110827.

NMKL 129, (2003), $2^{\text {nd }}$ Ed. Kostfiber, total, løselig og uløselig. Gravimetrisk bestemmelse i næringsmidler etter enzymatisk nedbrytning med MES/TRIS buffer. Total, Soluble, and Insoluble Dietary Fibre in Foods. EnzymaticGravimetric Method, MES/TRIS Buffer. (Codex endorsed method).

NMKL 160, (1998) Fett. Bestämning i livsmedel. Fat. Determination in foods.

NMKL 173, (2005), $2^{\text {nd }}$ Ed. Aske, gravimetrisk bestemmelse i levnedsmidler. Ash, gravimetric determination in foods. (Codex endorsed method).

NMKL 6, (2003), $4^{\text {th }}$ Ed. Nitrogen. Bestemmelse i levnedsmidler og goderstoffer efter Kjeldahl. Nitrogen. Determination in foods and feeds according to Kjeldahl (Codex endorsed method)

Oke, E. K., Idowu, M. A., Sobukola, O. P., Bakare, H.A. (2020). Nutrient composition, functional, physical and pasting properties of yellow yam (Dioscorea cayenensis) and jack bean (Canavalia ensiformis) flour blends. Carpathian Journal of Food Science and Technology, 12, 52-71.

Petroski, W., Minich, D.M. (2020). Is There Such a Thing as "Anti-Nutrients"? A Narrative Review of Perceived Problematic Plant Compounds. Nutrients, 12, 2929.

Peumans, W. J., Van Damme, E.J. (1995). Lectins as plant defense proteins. Plant physiology, 109, 347.

Popova, A., Mihaylova, D. (2019). Antinutrients in plant-based foods: A review. The Open Biotechnology Journal, 13, 68-76.

Romero, H. M., Santra, D., Rose, D., Zhang, Y. (2017). Dough rheological properties and texture of gluten-free pasta based on proso millet flour. Journal of cereal science, 74, 238-243.

Sharon, N., Lis, H. (1997). Microbial lectins and their glycoprotein receptors. New Comprehensive Biochemistry, 29, 475506.

Tarlak, F., Ozdemir, M., Melikoglu, M. (2020). The combined effect of exposure time to sodium chlorite $\left(\mathrm{NaClO}_{2}\right)$ solution and packaging on postharvest quality of white button mushroom (Agaricus bisporus) stored at $4^{\circ}$ C. Food Science and Technology, 40, 864-870.

Turkut, G.M., Cakmak, H., Kumcuoglu, S., Tavman, S. (2016). Effect of quinoa flour on gluten-free bread batter rheology and bread quality. Journal of Cereal Science, $69,174-181$.

Van der Poel A.F.B. (1990). Effect of processing on antinutritional factors and protein nutritional value of dry beans (Phaseolus vulgaris L.) A review of Animal Feed Science and Technology, 29- 179-208.

Vasconcelos, I. M., Oliveira, J.T.A. (2004). Antinutritional properties of plant lectins. Toxicon, 44, 385-403.

Werz, D.B., Seeberger, P.H. (2005). Carbohydrates as the next frontier in pharmaceutical research. Chemistry-A European Journal, 11, 3194-3206.

Yildiz, Ö., Dogan, I. S. (2014). Optimization of gluten-free cake prepared from chestnut flour and transglutaminase: Response surface methodology approach. International Journal of Food Engineering, 10, 737-746.

Yu-Wei, L., Wei-Hua, X. (2013). Effect of different processing methods on certain antinutritional factors and protein digestibility in green and white faba bean (Vicia faba L.), CyTA - Journal of Food, 11, 43-49. 
Zwolak, I. (2014). Vanadium carcinogenic, immunotoxic and neurotoxic effects: a review of in vitro studies. Toxicology mechanisms and methods, 24, 1-12. 